\title{
Effect of Land use Types on Soil Organic Carbon Stock at Sire Morose Sub Watershed, Hidabu Abote District of North Shoa Zone, Central Highland of Ethiopia
}

\author{
Dereje Girma $^{1,}$, Lemma Wogi $^{2}$, Samuel Feyissa ${ }^{2}$ \\ ${ }^{1}$ Oromia Agricultural Research Institute, Fitche Agricultural Research Center, Fitche, Ethiopia \\ ${ }^{2}$ School of Natural Resource Management and Environmental Science, Haramaya University, Haramaya, Ethiopia
}

Email address:

dergrima@gmail.com (D. Girma)

${ }^{*}$ Corresponding author

\section{To cite this article:}

Dereje Girma, Lemma Wogi, Samuel Feyissa. Effect of Land use Types on Soil Organic Carbon Stock at Sire Morose Sub Watershed, Hidabu Abote District of North Shoa Zone, Central Highland of Ethiopia. Science Research. Vol. 8, No. 1, 2020, pp. 1-6. doi: 10.11648/j.sr.20200801.11

Received: January 28, 2020; Accepted: March 3, 2020; Published: April 1, 2020

\begin{abstract}
Information about effects of different land use types on soil organic carbon stock is crucial for best land management practices and combating climate change and enhancing ecological restoration. The study was aimed to estimate the effect of land use types on soil organic carbon stock at sire morose sub watershed Hidbuabote district Ethiopia. Three land use types were selected from the sub watershed (Forest, grazing and cultivated land). Undisturbed core and disturbed composite soil samples were collected randomly from three sites with three replications from each land use type at two varying depths $(0-20 \mathrm{~cm}$ and $20-40 \mathrm{~cm})$ and subjected to laboratory soil analysis. Heterogeneity in soil C storage was observed across land use types and along soil depth due to disparity in spatial distribution of soil $\mathrm{C}$ densities arising from the influences of variations in land use types and management practices. Accordingly, the total mean values soil organic carbon stocks (SOCS) for forest land was $85.97 \mathrm{Mg} / \mathrm{ha}$, which was higher than that of grazing land $(83.45 \mathrm{Mg} / \mathrm{ha})$ and the lowest being that of cultivated land (49.54Mg/ha). Moreover, the average $\mathrm{CO}_{2} \mathrm{e}$ sink was $315.51 \mathrm{Mg} \mathrm{ha}^{-1}, 306.26 \mathrm{Mg} \mathrm{ha}^{-1}$ and $181.81 \mathrm{Mg} \mathrm{ha}^{-1}$ in soil of the forest, grazing and cultivated land, respectively. Relatively the result shows potential contribution of forestland use types to enhance soil organic carbon stocks and environmental protection.
\end{abstract}

Keywords: Soil Organic Carbon Stocks, Land Use Types, Soil Depth and Management Practices

\section{Introduction}

Land use change is one of the major causes of soil erosion and subsequent loss of soil organic carbon in the ecosystem [17]. Moreover, land use changes have been recorded to be the second largest source of anthropogenic source of green house gases accounting for $12-20 \%$ of carbon emission [10] Land use change has become prevalent in the sub Saharan Africa and more specifically in Kenya with the drivers being socio economic as well as political gears [21]. Soil carbon is primarily influenced by plant production through presence of microclimates, litter quality and carbon pathways and these factors affect rate of decomposition, which in turn influence nutrient availability for plant uptake, and carbon emissions released to the air [12].
Soil is the largest sink and store of global terrestrial $\mathrm{C}$ and an important part of the biosphere in sequestering $C$ [14]. It has a higher potential to store $\mathrm{C}$ compared to vegetation and atmosphere [1]. The global soil $\mathrm{C}$ pool is $2300 \mathrm{Pg}$, which is 3 times the size of atmospheric $\mathrm{C}(770 \mathrm{Pg})$ and 3.8 times the size of biotic pools (610 Pg) [13]. The SOC sequestration is mainly influenced by land use dynamics, management practices, soil depth, land security, and other soil variables like bulk density [14]. Land use dynamics governs the fate of SOC storage potential on global basis there by determining the state of climate change [11]. Changes in land use result in significant changes of net primary production, species composition, stand age, rooting distribution and quantity of litter and these factors affect SOC storage dynamics, either mitigating or aggravating climate change. 
Despite the tremendous land use changes from forest to grazing and cultivated lands in Ethiopia, particularly during the last five to six decades, the impacts of these changes on soil properties are not well studied and documented. In the Ethiopian highlands, population pressure, which accounts for $85 \%$ of the country's total population as well as $67 \%$ of its livestock population, has pushed cultivation and livestock grazing to steep slopes and fragile lands causing serious overgrazing and soil erosion [9]. The exacerbation of soil erosion is attributed to poor soil qualities like low soil organic carbon (SOC) among others. Moreover, with the accelerated loss of soil, there is severe loss of SOC from the surface and subsurface soil noting that even slight changes in the soil organic carbon pool can significantly affect the global carbon cycle [18]. Appropriate land use types with proper management among others may control soil erosion, the major cause of SOC loss from the surface soil. However, the effect of different land use types and associated management practices on soil organic carbon stock has not been assessed and documented for the study area. In order to put the proper recommendations for sustainable utilizations of soil resources and quality, the information about effects of land use types on soil organic carbon stocks are essential. Therefore, the objective of this study was to estimate the effect of different land use types on soil organic carbon stock at Sire morose subwatershed in Hidebuabote district.

\section{Materials and Methods}

\subsection{Description of the Study Area}

The study was conducted at Sire Morose sub watershed, located in Hidebu Abote District of North Showa Zone, Oromia Regional State. The sub watershed is located at about
$43 \mathrm{~km}$ north of zone town, Fitche, and $142 \mathrm{~km}$ northwest of Addis Ababa. The geographical location of the watershed is in $9.81^{\circ} 47^{\prime}$ to $10.08^{\circ} 11^{\prime} \mathrm{N}$ and $38^{\circ} 27^{\prime}$ to $38.67^{\circ} 43^{\prime} \mathrm{E}$ with an average altitude of 2149 meter above sea level (masl). The main rainy season in the area is from mid-June to midSeptember and the short rainy season (Belg) is from March to May. According to the weather record from Gundo-meskel Meteorology Station the average annual rainfall and mean annual minimum and maximum temperatures of the area based on the last 10 years records are $971 \mathrm{~mm}$, and $9.7^{\circ} \mathrm{C}$ and $21^{\circ} \mathrm{C}$, respectively (Figure 2 ).

\subsection{Soil, Vegetation and Farming System}

The dominant soil of the study area is Nitisols and Vertisols [8]. The vegetation type of the district is characterized by tree, bushes, and shrubs. The most dominant tree species found in the area Croton macrostachyus, Cordia africana, Olea europaea, Vernonia amygdalina and Erythrina abyssinica. The agricultural activities in the district are mainly characterized by the presence of subsistence mixed farming system of both crop and livestock production. There are also households engaging in off-farm activities. On-farm trees are the main source of fuel wood demand for the whole communities. The major cereals crops are being produced in the district are tef, wheat, sorghum, and barley and vegetables (onion, potato, redroot, tomato and cabbage). Based on climatic classification, the farming systems vary in such a way that in low land areas, the farmers practice crop production and as in the midland and highland areas both crop and livestock productions are the common practice. Generally, the main sources of income for the local communities are crops and livestock.

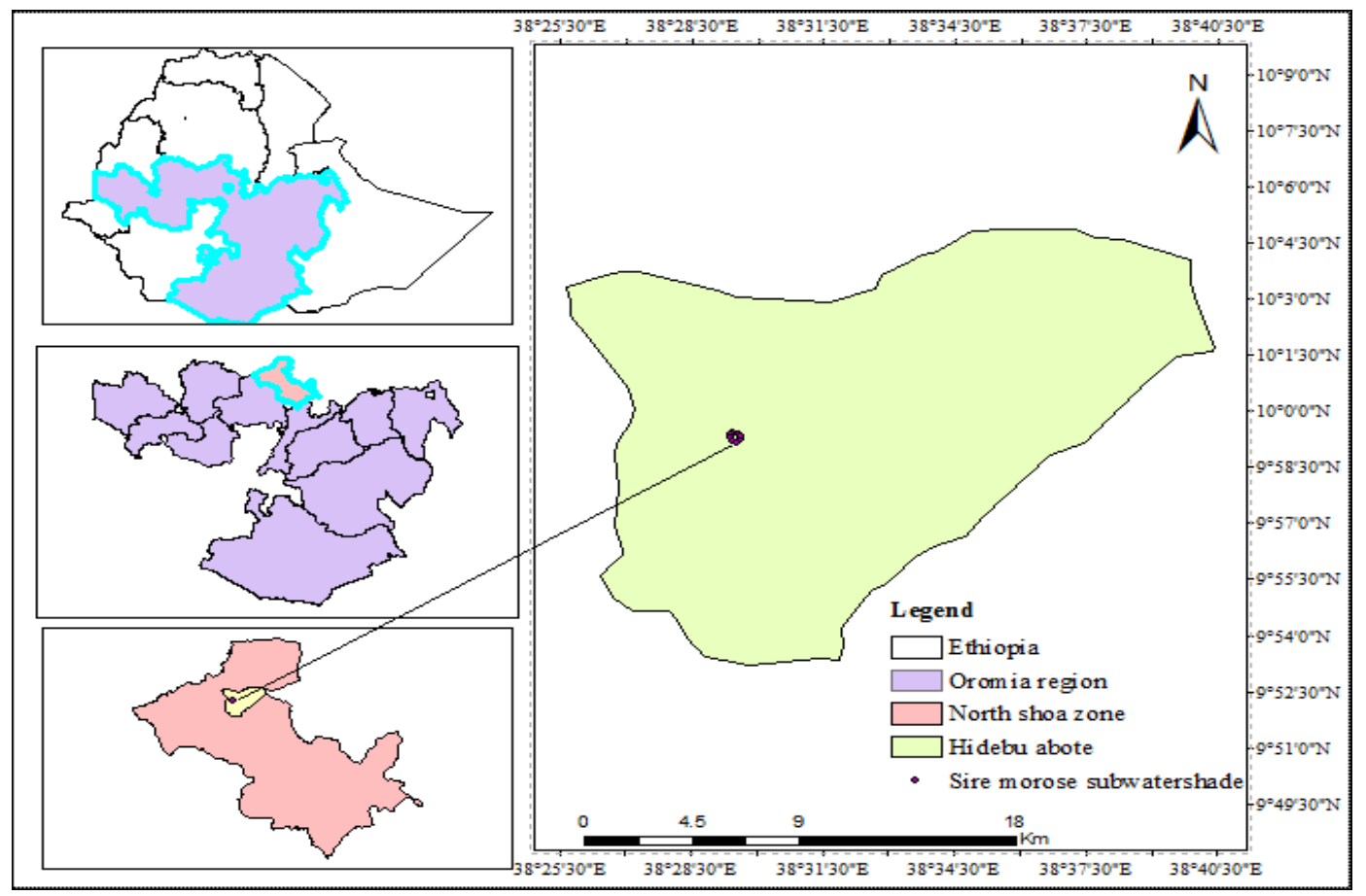

Figure 1. Location of the study area. 


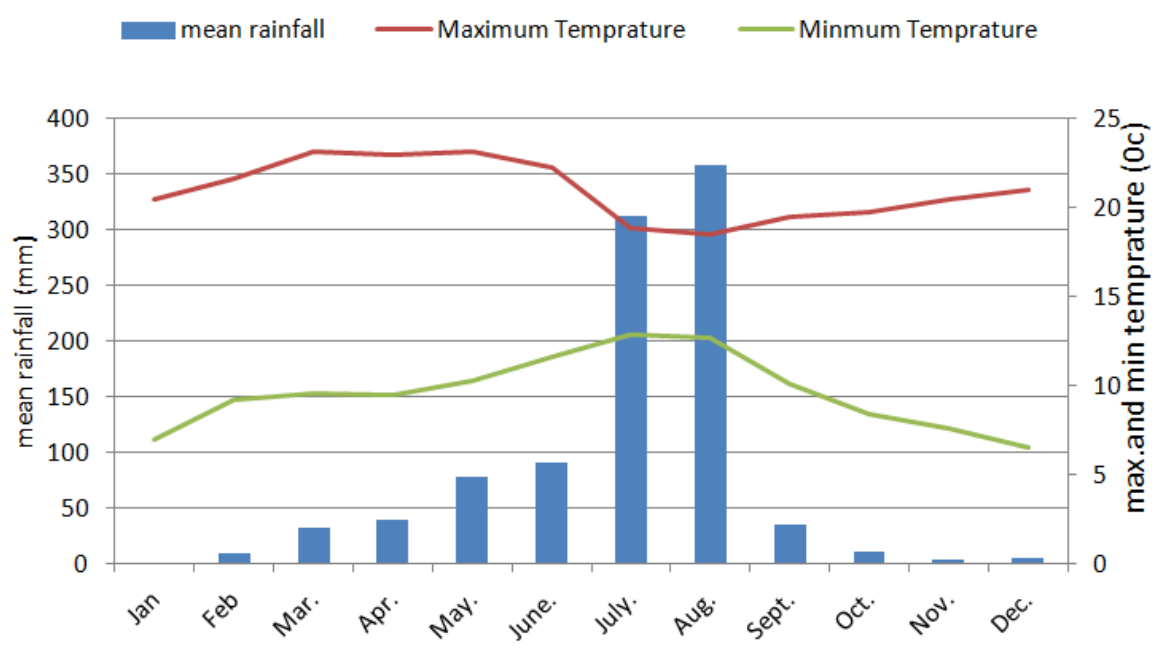

Figure 2. Mean monthly rainfall and mean maximum and minimum temperatures of the study area (Gundo-meskel Meteorology Station).

\subsection{Site Selection and Soil Sampling}

Assumption was made in this research approach that soil conditions and parameters under the three land uses were similar before changes in the land use have been introduced. Differences due to lateral movement of soil material in the watershed slopes before land use changes were assumed to be very small. The observed differences in present soil conditions and other parameters are assumed as being caused by the present land use types and management practices.

Primarily, a general visual field survey of the area was carried out to have a general view of the land use/land cover and management practice in the study area. Then three land uses were selected based on the similarity of topography, aspects, and soil and replicated three times. Following this, three land uses (cultivated, forest and grazing lands) were selected and Global Positioning System (GPS) and clinometers were used to identify the geographical locations and slopes of the sampling points, respectively. Composite soil samples were collected from the three land use types (cultivated, grazing and forest) by two soil depths $(0-20 \mathrm{~cm}$ and $20-40 \mathrm{~cm}$ ) with three replications. The whole factors were situated on the same slope and topography. Both undisturbed and disturbed soil samples were taken from two soil depths from twelve sampling point based on the heterogeneity of land unit in a zigzag manner. Undisturbed soil samples were taken by core sampler to measure the soil bulk density, whereas the disturbed soil samples were taken by using an auger to measure soil organic carbon.

During the collection of soil samples, gravel materials, dead plants, old manures, areas near trees and compost pits were excluded. This is to minimize the differences variation, which may arise because of the dilution of soil OM due to mixing through cultivation and other factors. After these materials and areas were separated, 18 composite soil samples were collected from representative land use types. Then after, about one kilogram of the soil samples from 18 composite soil samples were sub-sampled and packed by plastic bags with tightly and labeled carefully with the location, representative field and depth of soil and transport to Laboratory.

\subsection{Soil Sample Preparation and Analysis}

The soil samples collected from the study area were airdried ground and passed through a 0.5 sieve for soil organic carbon (OC) and analyses were done at Fitche Soil Research Center by the wet oxidation method as described by [27]. Bulk density of the soil samples was determined from undisturbed soil samples collected using the core sampling method [19]. The core samples were oven dried at $105^{\circ} \mathrm{C}$ for 24 hours [3] and the bulk densities were calculated by dividing the masses of the oven dry soils ( $\mathrm{g}$ ) by their respective volumes $\left(\mathrm{cm}^{3}\right)$ of core sampler, as they exist naturally under field conditions.

\subsection{Estimation of Soil Organic Carbon Stock}

The SOC stock per hectare $\left(\mathrm{Mg} \mathrm{C} \mathrm{ha-}{ }^{1}\right)$ was estimated using [26] equation

$$
\text { SOCdi }=\frac{\text { OC } * \text { BD } * \text { Soil depth }(\mathrm{m}) * 10,000 \mathrm{~m}^{2} \mathrm{ha}^{-1}}{100}
$$

Where: SOCdi is the amount of OC stock per unit hectare of land $\left(\mathrm{Mg} \mathrm{ha}^{-1}\right)$ to specified soil depth (di) and Dry bulk density soil samples in drying oven at $105^{\circ} \mathrm{C}$ for a minimum of 24 hours.

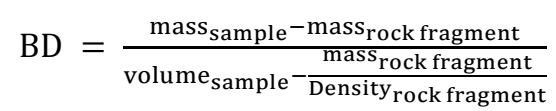

Where: $\mathrm{BD}=$ bulk density $\left(\mathrm{g} \mathrm{cm}^{-3}\right), \mathrm{DM}=\operatorname{dry}$ mass $\left(\mathrm{g} \mathrm{cm}^{-3}\right)$, VOL core $=$ mineral soil core volume $\left(\mathrm{cm}^{-3}\right), \mathrm{M}_{\text {coarse frag }}=$ mass of coarse fragments $(\mathrm{g})$, Dens $_{\text {rock frag }}=$ density of rock fragments $\left(\mathrm{g} \mathrm{cm}^{-3}\right)$. Note that, bulk density is for the $<2 \mathrm{~mm}$ fraction, coarse fragments are $>2 \mathrm{~mm}$. The density of rock fragments is often given as $2.65\left(\mathrm{~g} \mathrm{~cm}^{-3}\right)$ [5]. Then $\left(\mathrm{g} \mathrm{cm}^{-3}\right)$ was converted to $\mathrm{Mg} \mathrm{m}{ }^{-3}, \mathrm{OC}=$ is the organic carbon concentration (\%) data obtained from the laboratory from soil analysis result for each soil depth. In this equation, $\mathrm{C}$ must be expressed as a decimal 
fraction. Based on the $\mathrm{OC}$ content of each soil layer per hectare $\left(\mathrm{Mg} \mathrm{C} \mathrm{ha}^{-1}\right)$, the amount of SOC stored in soils per specific area of land was estimated as follows:

$$
\mathrm{SOCs}=\Sigma \mathrm{SOC}_{\mathrm{di}}
$$

Where: SOCs is the OC stored in soils per specified area $(\mathrm{Mg})$ and SOCdi is Mg ha-1 of OC stored in the $i$ th soil depth

\subsection{Estimation of Carbon Dioxide Equivalence}

The carbon dioxide equivalence is simply multiply by the atomic weight difference between $\mathrm{C}$ and $\mathrm{CO}_{2}$ (44/12).

$$
\mathrm{CO}_{2} e_{\text {total }}=C_{\text {total }} * \frac{44}{12}
$$

where: $\mathrm{CO}_{2} \mathrm{e}=$ Carbon dioxide equivalent with measured depth, $C_{\text {total }}=$ Carbon stocks with measured depth, 44/12 = Conversion factor to convert Carbon into Carbon Dioxide

\subsection{Statistical Analysis}

Descriptive statistics was used to reveal the relationships between the three land use types. Land use types were compared with each other based on soil organic carbon stock.

\section{Results and Discussion}

\subsection{Soil Organic Carbon}

Result revealed that land uses and soil depths influenced soil organic carbon (OC) content. Considering means, the highest $(3.02 \%)$ OC was recorded in the surface soil of the forestland, whereas the lowest $(0.60 \%)$ was recorded in the subsurface soil of the cultivated land (Table 1). These results imply that under the cultivated land use type, losses of soil organic carbon were not fully compensated by organic matter inputs from the crop residues. The lowest OC in soil of cultivated land could also be due to the effects of the tillage practices coupled with reduced soil organic matter inputs and almost complete removal of crop residues from the cultivated fields for various reasons. On the other hand, less soil disturbance in the forestland and grazing land might have apparently led to the observed increase in organic carbon content as compared to the soil under cultivated land. Moreover, the surface soil of the forest land had shown relatively higher OC content than the surface soil of the grazing land (Table 1). As per OC rating proposed by [23], the OC content of the soils in the study area varied from moderate status in the cultivated and grazing lands to high in the forestland.
Table 1. Soil bulk density after removing coarse fragment and $O C$ concentration under different land uses and soil depth.

\begin{tabular}{llll}
\hline LU types & Soil depth $\mathbf{( c m )}$ & BD $\left(\mathbf{g} / \mathbf{c m}^{\mathbf{3}}\right)$ & $\mathbf{O C} \mathbf{( \% )}$ \\
\hline Forest land & $0-20$ & 0.91 & 3.02 \\
& $20-40$ & 1.02 & 1.52 \\
Grazing land & $0-20$ & 1.05 & 2.51 \\
& $20-40$ & 1.09 & 1.41 \\
Cultivated land & $0-20$ & 1.12 & 1.59 \\
& $20-40$ & 1.16 & 0.60 \\
\hline
\end{tabular}

$\mathrm{LU}=$ Land use, $\mathrm{BD}=$ Bulky desity

\subsection{Soil Organic Carbon Stock and Carbon Dioxide Equivalence}

The results showed soil carbon stock (SOCS) $(\mathrm{Mg} / \mathrm{ha})$ variations with respect to the three land use types and depth (Table 1 and figure 3). The mean values for SOCS of the forest was different from the other land uses for respective soil depth (Table 1). In the surface soil of the forest land, SOCS was $54.96 \mathrm{Mg} / \mathrm{ha}$, which was higher than that of grazing land $(52.71 \mathrm{Mg} / \mathrm{ha})$, the lowest being that of cultivated land $(35.62 \mathrm{Mg} / \mathrm{ha}$ ) (Table 2). For the subsurface soil the highest mean value of SOCS was recorded for the forest land followed by grazing and cultivated lands (Table 2). Soil organic carbon stocks consistently declined with depth in all the three land uses (Table 2 and figure 3). This was attributed to low $\mathrm{OC}$ input at subsoil and the effect of bulk density. The higher SOCS recorded for soil of the forestland may be mainly because of the higher biomass inputs and low rate of litter decay. [24] also found a higher mean carbon stock in natural forest than in all the other land cover categories in Chilimo, a dry Afromontane forest in Ethiopia. Relatively SOCS of grazing land was the lower compared to forestland. This might be linked to the uncontrolled grazing within the area. The subsequent disruption of carbon input and excessive harvesting ground biomass by livestock alter the carbon cycle within the ecosystem. According to [16], this exposure hastens the litter turnover rates, leading to SOM oxidation and expanding $\mathrm{CO}_{2}$ released into the atmosphere. The lowest soil organic carbon recorded for soil of cultivated land might be due to the low input of organic matter to the soil and high rates of oxidation of soil organic matter due to tillage. Study by [15] revealed depletion of $23.50 \mathrm{Mg} \mathrm{ha}{ }^{-1}$ SOC within 33 years of continuous cultivation after deforestation of tropical forest in highlands of Ethiopia. Conversion of natural vegetation to agricultural land results in the mineralization of SOC, thus reducing SOCS and increasing atmospheric $\mathrm{CO}_{2}$ concentrations as indicated by [7].

Table 2. Soil organic carbon stock and $\mathrm{CO}_{2}$ e capacity as influenced by land use types and soil depth in the study area.

\begin{tabular}{lllll}
\hline LU types & \multicolumn{2}{l}{ SOCS (Mg/ha) } & Total SOCS per specific land use & Equiv. CO, per land use \\
\hline & $\mathbf{0}-\mathbf{2 0} \mathbf{c m}$ & $\mathbf{2 0}-\mathbf{4 0 c m}$ & $\mathbf{( M g} / \mathbf{h a})$ & $\mathbf{( M g} / \mathbf{h a})$ \\
\hline Forest land & 54.96 & 31.01 & 85.97 & 315.51 \\
Grazing land & 52.71 & 30.74 & 83.45 & 306.26 \\
Cultivated land & 35.62 & 13.92 & 49.54 & 181.81 \\
\hline
\end{tabular}

$\mathrm{LU}=$ Land use, $\mathrm{SOCS}=$ Soil organic carbon Stock, Equiv. $\mathrm{CO}_{2}=$ Carbon dioxide equivalence 
When the total SOCS (Mg/ha) (Table 2) was estimated on per specific land use, the average SOC storage capacity varied from $85.97 \mathrm{Mg} \mathrm{ha}^{-1}$ in soil of the forest to $83.45 \mathrm{Mg} \mathrm{ha}^{-}$ ${ }^{1}$ in soil of the grazing land and $49.54 \mathrm{Mg} \mathrm{ha}^{-1}$ in soil of cultivated land (Table 2). The SOCS in forest land of the present study is higher than the finding of [2] who reported SOCS of $35.24 \mathrm{Mg} \mathrm{ha}{ }^{-1}$ for soil depth $(0-60 \mathrm{~cm})$ for Afromontane forest soil. The SOCS in cultivated land of the present study is also higher than the finding of [2] who reported SOCS of $14.16 \mathrm{Mg} \mathrm{ha}^{-1}$ for cultivated soil and a also higher than $36.80 \mathrm{Mg} \mathrm{ha}^{-1}$ reported by [22].

The average $\mathrm{CO}_{2} \mathrm{e}$ sink was $315.51 \mathrm{Mg} \mathrm{ha}^{-1}, 306.26 \mathrm{Mg}^{-}$ 1 and $181.81 \mathrm{Mg} \mathrm{ha}^{-1}$ in soil of the forest, grazing and cultivated land, respectively (Table 2). The higher $\mathrm{CO}_{2} \mathrm{e}$ was recorded in forestland followed by grazing and cultivated land. The result was in accordance with the conclusion of [25], who reported that intensive and continuous cultivation forced oxidation of $\mathrm{OC}$, and thus resulted in reduction of SOC. Furthermore, [4] specified that variation of SOC across land uses could be attributed to the number of trees, tree species, size of trees and other disturbances. Agricultural cultivation is known to decrease carbon storage $[6,22]$ and result in a net flux of carbon to the atmosphere [20]. It may be relatively the emission of $\mathrm{CO}_{2}$ from the cultivated land as manifested by loss of SOC. Annual burning and complete removal of crop residues and continuous tillage are the major causes for low SOC in cultivated soil. In croplands, the critical issue in increasing SOC sequestration is the addition of crop residues, avoiding residue burning, manuring, and the reduction in soil disturbance through conservation tillage or no-till systems [20]. It is possible to maintain SOC levels of cultivated land fairly close to that under forest through management systems including fallowing and conservation tillage.

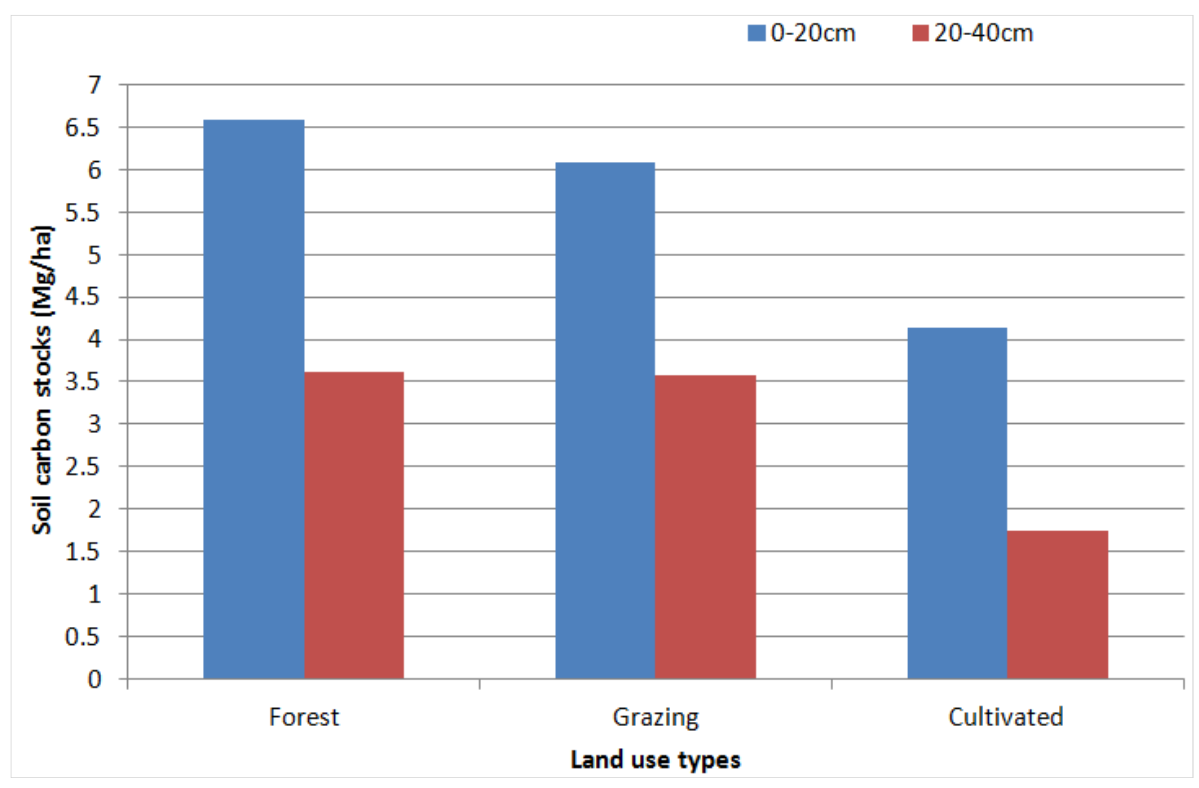

Figure 3. Carbon stocks under different land use types.

\section{Summary and Conclusion}

In the present study area, practices of exceptional deforestation, overgrazing and intensive cultivation of soil with very low inputs over many years are common. Such practices may disturb soil stracture and result in varations and even deterioration in soil quality attributes among land use types of same soil type. Nevertheless, the impact of the different land uses on major soil attributes have not been quantified in the study area. Furthermore, the effects of soil depth and land use types on soil carbon stock have not been studied in the study are. Three land uses were selected from the sub watershed (Forest, grazing and cultivated lands), and GPS and clinometers were used to identify the geographical locations and slopes of the sampling sites, respectively. Eighteen composite soil samples and eighteen separate soil core samples for bulk density determination were prepared for the analysis of soil organic carbon stock of the soil. Soil carbon stocks were varied across land uses due to disparity in spatial distribution of soil $\mathrm{C}$ densities arising from the influences of variations in land use types, soil depth, and management practices. In the surface soil, the mean SOCS in the forestland was higher than grazing and was the lowest in cultivated land. Moreover, the mean $\mathrm{CO}_{2} \mathrm{e}$ sink was higher in the surface soil of forest than in the surface soil of the grazing and cultivated land.

In general, the information generated from the present study on the effect of land use types on soil organic carbon stock might be helpful for proper management of land in the area. This study showed that conversion of natural ecosystem into crop/cultivated land ecosystem has resulted in deterioration of the soil organic carbon stock. Therefore, improved management practices like conservation tillage or zero-tillage, fallowing, residue incorporation, tree-crop agroforestry combined with addition of animal and farmyard manures can improve the SOC stock of the cultivated soil 
and helps to mitigate climate change.

\section{References}

[1] Bellamy, P. H., Loveland, P. J., Bradley, R. I., Lark, R. M., and Kirk, G. J. D. 2005. Carbon losses from all soils across England and Wales. Nature 437: 245-24

[2] Birhanu Iticha, Kibebew Kibret, Muktar Mohammed. 2017. Changes in Soil Carbon Storage Potential Following Conversion from Afromontane Forest to Plantations and Cultivated Land in Komto Watershed, Western Ethiopia, P. 30-31

[3] Blake, G. R. 1965. Bulk density. Methods of soil Analysis. Monogr Ser, (9 Part 1): 374-390.

[4] Bonnell, T., Reyna-Hurtado, R., and Chapman, C. 2011. Postlogging recovery time is longer than expected in an East African tropical forest. Forest Ecology and Management 261: 855-864.

[5] Christopher Poeplau, Cora Vos, and Axel Don. 2017 Soil organic carbon stocks are systematically overestimated by misuse of the parameters bulk density and rock fragment content

[6] Davidson, E. A., and Ackerman, I. L. 1993. Changes in soil carbon inventories following cultivation of previously untilled soils. Biogeochemistry, 20: 161-193.

[7] Don, A., Schumacher, J., Freibauer, A. 2011. Impact of tropical land-use change on soil organic carbon stocks- a meta-analysis. Global Change Biology 17: 1658-1670.

[8] Hidebu Abote Agricultural and Natural Resource Office (HAANRO). 2016. Report about natural resource of Hidebu Abote to North Shoa Zone Agricultural and Natural Resource Office, Fitche, Ethiopia.

[9] Heluf Gebrekidan and Wakene Negassa. 2006. Impact of land use and management practices on chemical properties of some soils of Bako area, Western Ethiopia. Ethiopian Journal of Natural Resources, 8 (2): 177-197.

[10] IPCC (Intergovernmental Panelon Climate Change). 2007. The physical Science Basis. Contribution of Working Group I to the Fourth Assessment Report of the Intergovernmental Panel on Climate Change, Cambridge: Cambridge University Press

[11] Jackson, R. B., Schenk, H. J., Jobbágy, E. G., Canadell, J., Colello, G. D. 2000. Below ground consequences of vegetation change and their treatment in models. Ecol. Applic.

[12] Kindermann, G., Obersteiner, M., Sohngen, B., Sathaye, J., Andraska, K., and Rametsteiner, E. 2008. Global cost estimates of reducing carbon emissions through avoided deforestation. Proceedings of the National Academy of Sciences.

[13] Lal R. 2001. Potential of desertification control to sequester carbon and mitigate the greenhouse effect. Climate Change, 15: $35-72$.
[14] Lal, R. 2002. The potential of soils of the tropics to sequester carbon and mitigate the greenhouse effect. Advances in Agronomy, 76: 1-30.

[15] Mulugeta, L., Bekele, L., Demel, T. (2005). Changes in soil carbon and total nitrogen following reforestation of previously cultivated land in the highlands of Ethiopia. Ethiopian Journal of Science 28 (2), 99-108.

[16] Murty, D., Kirschbaum, M. F. U., Mcmurtrie, R. E. and Mcgilvray, H. 2002. Does Conversion of Forest to Agricultural Land Change Soil Carbon and Nitrogen? A Review of the Literature. Global Change Biology, 8: 105-123.

[17] Nie, X. J., Zhao, T. Q., and Qiao, X. N. 2013. Impact of soil erosion on organic carbon and nutrient dynamics in an alpine grassland soil. Soil science and plant nutrition, 59 (4): 660668 .

[18] Powlsonand Goulding, K. W. 2011. Soil management in relation to sustainable agriculture and ecosystem services. Food policy, 36: s72-s87.

[19] Sahlemedhin Sertsu and Taye Bekele. 2000. Procedures for soil and plant analysis. National Soil Research center Techl. Paper, 74. NFIA, Addis Ababa, Ethiopia

[20] Schlesinger, W. H. 1984. The world carbon pool in soil organic matter: (pp. 111-124) A source of atmospheric $\mathrm{CO}_{2}$. In J. R. Trabalka, \& D. E. Reichle (Eds.), The Changing Carbon Cycle: A Global Analysis, New York: Springer-Verlage

[21] Serneels, S., and Lambin, E. F. 2001. Proximate causes of land use change in Narok District, Kenya; a spatial statistical mode. Agriculture. Ecosystems and Environment, 85 (1): 65-81.

[22] Solomon Dawit, Fritsch, F., Tekalign Mamo, Lehman, J., and Zech, W. 2002. Soil Organic Matter Composition in the Subhumid Ethiopian Highlands as Influenced by Deforestation and Agricultural Management. Soil Science Society of America Journal, 66: 68-82

[23] Tekalign Tadese. 1991. Soil, plant, water, fertilizer, animal manure and compost analysis. Working Document No. 13. International Livestock Research Center for Africa, Addis Ababa

[24] Tesfaye, M., Bravo, F., Ruiz-Peinado, R., Pando, V. and Bravo-Oviedo, A. 2016. Impact of changes in land use, species and elevation on soil organic carbon and total nitrogen in Ethiopian Central Highlands. Geoderma, 261 (Supplement C): 70- 79. doi: 10.1016/j.geoderma.2015.06.022

[25] Wakene Negassa and Heluf Gebrekidan. 2004. The impact of different land use systems on soil quality of western Ethiopia, Alfisols. International Research on Food Security: Natural Resource Management and Rural Poverty Reduction through Research for Development and Transformation, pp. 1-7.

[26] Walker, SM, Pearson, TRH., Casarim, FM., Harris, N., Petrova, S., Grais, A. 2012. Standard Operating Procedures for Terrestrial Carbon Measurement: Winrock International.

[27] Walkley, A. and Black, I. A. 1934. An examination of the different method for determining soil organic matter and a proposed modification of the chromic acid titration method. Journal of Soil science, 37 (1): 29-38. 